Kala'lembang, A. (2021), "Digitalization in increasing SMEs productivity in the post COVID-19 pandemic period", Management and entrepreneurship: trends of development, 2(16), pp. 101-110. Available at: https://doi.org/10.26661/2522-1566/2021-1/16-08.

ENTREPRENEURSHIP, TRADE AND EXCHANGE ACTIVITIES

RECEIVED:

18 April 2021

ACCEPTED:

18 May 2021

RELEASED:

20 June 2021
UDC 338.312

DOI 10.26661/2522-1566/2021-1/16-08

\title{
DIGITALIZATION IN INCREASING SMES PRODUCTIVITY IN THE POST COVID-19 PANDEMIC PERIOD
}

\author{
Adriani Kala'lembang \\ Universitas Negeri Malang \\ Indonesia \\ ORCID ID: 0000-0003-3173-9310
}

\section{Authoremail: adriani.1904139@students.um.ac.id}

\begin{abstract}
The COVID-19 pandemic caused the global upheaval which resulted in the economic growth to be stunted and had a negative impact on the sustainability of SMEs. The panic occurred causing uncontrolled spending in order to promote the recovery. This study aims to examine the post COVID-19 pandemic opportunities for SMEs by utilizing digitization. With the use of SMEs digitalization, it is easy to attract and retain potential customers, ameliorate communication, save costs, and improve relationships with business partners. The author considers digitization as a smart solution to increase SMEs productivity.
\end{abstract}

Keywords: SMEs, COVID-19, digitalization.

JEL Classification: M11, M20.

\section{INTRODUCTION}

Since the announcement of the first COVID-19 case occurrence on March 2, 2020 until now, the impact still has not ceased to be felt. In dealing with the COVID-19 pandemic, the government has taken steps to implement the Large-scale Social Restriction (PSBB) policy, which is one of the options used within the pandemic. The government applies the PSBB system and considers it to be an effective way to reduce the spread of COVID-19. However, the PSBB system was faced with rejection since the restrictions had a negative impact on community activities. This would directly affect the sectors related to the daily mobility of the society. The sectors of tourism, transportation, manufacturing as well as food and social sectors were adversely affected by this policy.

Micro, Small, and Medium Enterprises (MSMEs) are among the drivers of the economic sector which has also had a severe impact due to the pandemic. According to the data of the Ministry of Cooperatives and Small Business, as many as 2,322 cooperatives and 185,184 SMEs actors were affected by the pandemic (beritasatu.com). The SMEs sectors, which suffered most, were those of food and beverages which experienced a decreased demand, hampered distribution, and capital. At least $39.9 \%$ of SMEs decided to reduce the stock of goods and $16.1 \%$ chose to reduce the number of employees due to closures of the physical stores.

The government has used various ways so that SMEs can survive and continue to develop 
after the pandemic, including by providing capital and credit relief, and also supporting the digitization of SMEs. The transformation of SMEs needs to be continuously strengthened through optimizing the use of digital technology in order to take advantage of one of the main lessons of the health crisis, namely the use of digital technology for daily activities. The digital era has changed the way of management in business activities (Steenkamp, 2020).

Based on the important role of SMEs, namely in increasing the share in the economy and exports, these enterprises are among the priorities for further development. The experience gained by SMEs during the pandemic still shows resilience and has the potential to increase even more after the pandemic. The trend of digitizing SMEs is one of the ways to arouse their activities. Digitalization strengthens the SMEs position by expanding the scope of their activities and encouraging innovation (Autio et al., 2018). It is time for business people to implement a digital business strategy (Bharadwaj et al., 2013)

\section{LITERATURE REVIEW}

To create new business opportunities, Industry 4.0 transformation provides many choices and brings efficiency to the production process, both for products and services, regardless of whether the enterprises are producers or distributors (Arnold et al., 2016). The government takes part in it by providing stimulation through financial funding for digitizing SMEs players so that they can compete in national and international markets (Autio et al., 2018).

With digitalization that continues to grow, almost every success in each sector has happened due to using IT. Thus, business people need to carry out digital innovation to improve or change their business model. If they fail to develop faster than their competitors, they risk losing their competitive advantage. With rapid technological changes, many businesses are feeling pressure to digitize. This pressure is constantly increasing due to the preferences (tastes) and expectations of customers and users.

Digitalization is the use of digital technology to increase business as well as income, to innovate and create a digital culture (Svadberg et al., 2019; Zhang et al., 2015). Digitalization is the use of new technology to enable business growth to be greater (Fitzgerald et al., 2013). Some examples of digitalization applications include mobile devices, big data analytics, cloud, social media, 3D printing, additive manufacturing, and artificial intelligence (AI). In entering Industry 4.0, digitalization is seen as a basic need for business people to develop and innovate (Nambisan et al., 2019; Schuh et al., 2017).

\section{PAPER OBJECTIVE}

The deterioration experienced by SMEs during the pandemic made them have to change the ways and processes of running their businesses. This study aims to examine the extent to which digitalization has raised the productivity of SMEs after the COVID-19 pandemic.

\section{METHODOLOGY}

This study uses a literature study approach by collecting library data, reading and taking notes, and managing research materials. Literature studies are used with the aim of finding a basis for building a theory and framework of thought. By studying the literature, researchers have a broader and deeper understanding of the problems to be studied. The data used comes from journals, scientific articles, literature reviews that contain the concepts studied. 
Kala'lembang, A. (2021), "Digitalization in increasing SMEs productivity in the post COVID-19 pandemic period", Management and entrepreneurship: trends of development, 2(16), pp. 101-110. Available at: https://doi.org/10.26661/2522-1566/2021-1/16-08.

\section{RESULT AND DISCUSSION}

The economic crisis that has hit Indonesia has shown us that Micro, Small, and Medium Enterprises (MSMEs) are the backbone and support that protect Indonesia from various economic problems. SMEs are also a significant force for economic growth not only in Indonesia, but in every country (Lawal and Akingbade, 2018). Now, SMEs are back in the spotlight to support the acceleration of digital transformation in the post-pandemic era. SMEs play an important role in the infrastructure development with the aid of science and technological advances to increase national productivity (Khalique et al., 2018). Currently, SMEs players are required to find alternatives to survive in the midst of the pandemic and switch after the COVID-19 pandemic. Figure 1 shows the results of a Mandiri Institute survey, according to which as many as $85 \%$ of SMEs players in the regions under study have been already using digital technology, while the rest are still offline.

\section{Online \& Offline Channel Penetration in Indonesia}

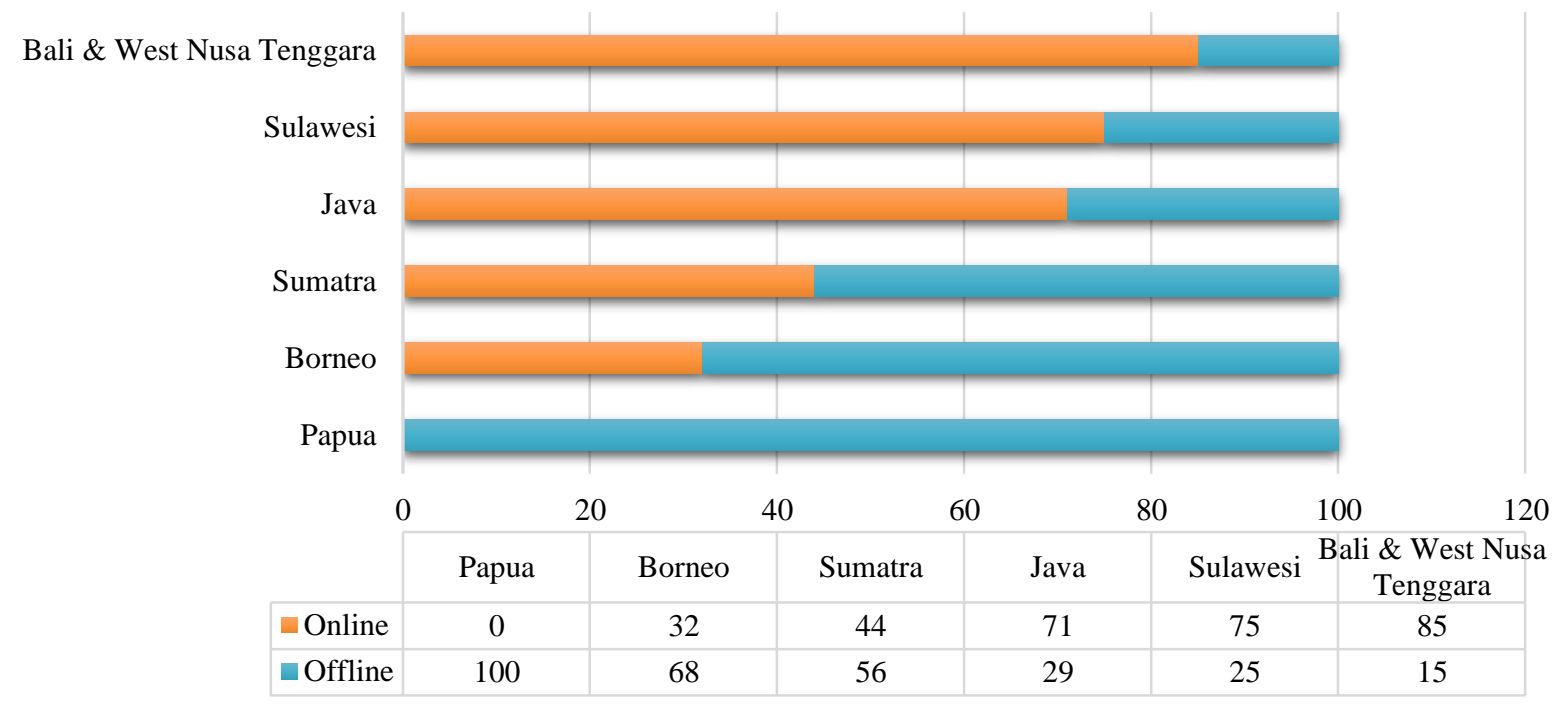

Figure 1. Online \& Offline Channel Penetration in Indonesia

\section{Source: Mandiri Institute survey (Indonesian Economic and Business Data Center, 2021)}

With the rapid development of technology, many SMEs have adopted an online digital system that is well managed and can facilitate with their business partners (Fairchild, 2005). Business people who tend to adopt the digitalization system have more potential to innovate in improving their business (Caniato et al., 2016). With digitalization, the financing process is cheaper than in traditional businesses (Perego and Salgaro, 2010). Businesses that use a digitization system will have a significant impact on their business performance and be more flexible (Ali et al., 2018; Lorenz et al., 2020). This is also proved by the research conducted by Maiti and Kayal, (2017), which states that digitization improves the performance of MSMEs. The high adoption of digitization provides positive results and can strengthen the independence of SMEs (Oliveira et al., 2021). Bank Rakyat Indonesia (BRI) argued that the SMEs business has resumed its growth after 
being hit by the pandemic. This can be seen from the Bank Rakyat Indonesia SMEs Business Activity Index (BMSI) which shows an increase in the third quarter of 2020. Figure 2 shows the role of each business actor in the process: micro-businesses are gradually increasing the number of workers, small businesses are increasing the inventory of finished goods, and medium businesses are increasing the production volume.

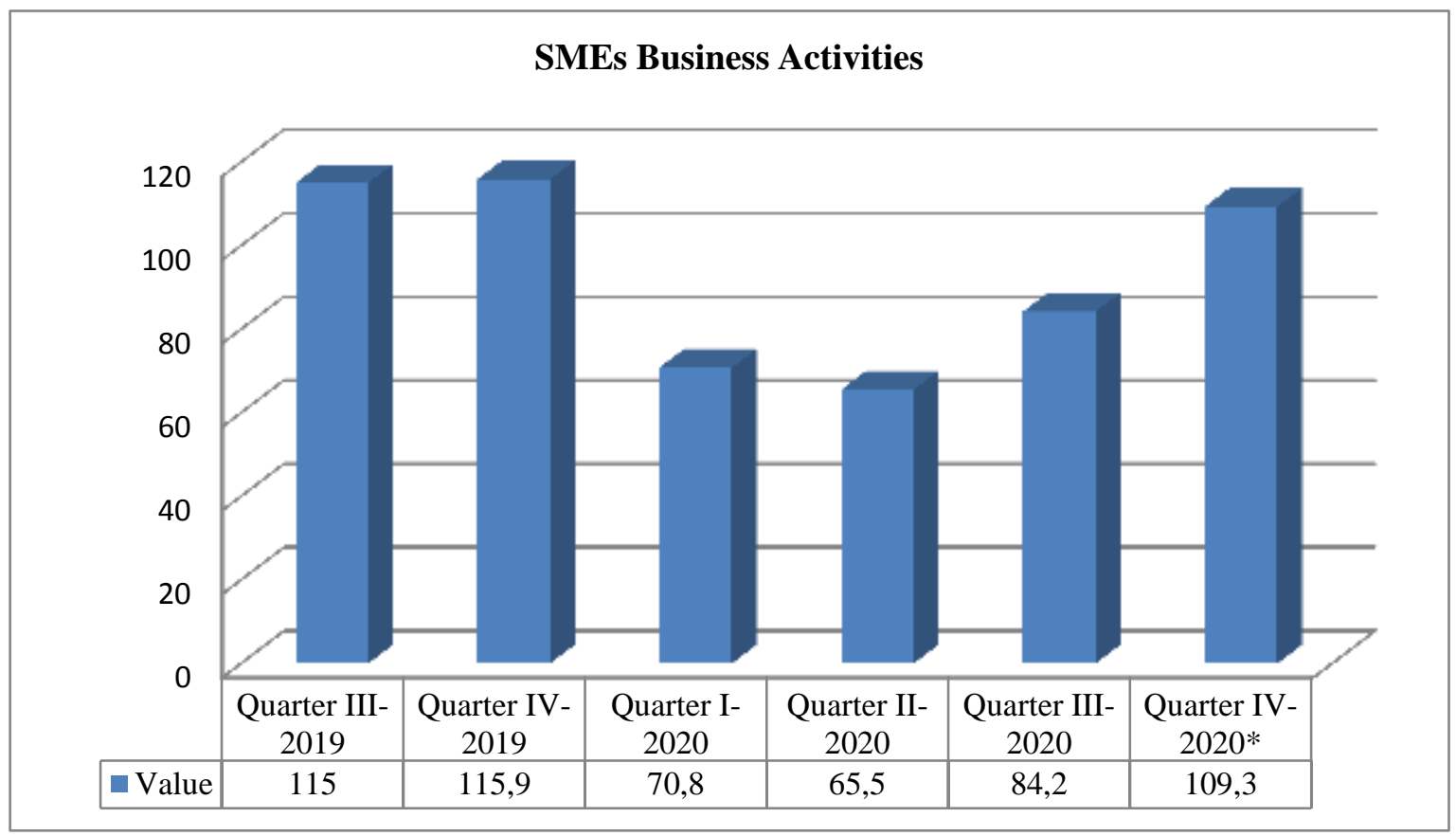

Figure 2. SMEs Business Activities

Source: Indonesian Economic and Business Data Center, 2021

Digitalization has become an important part of daily activities to the extent it can change the consumer behavior. Digitalization is positively related to business growth, performance, and competitiveness. Marketing with a digital system provides good opportunities to find new customers and can be more efficient in reaching customers (Karjaluoto and Heikki Karjaluoto, 2015). In addition, digitalization can also change the buying and selling transaction system, which initially used notes; then with the digital transaction technology, it turned into a digital transaction system (Gavrila Gavrila and de Lucas Ancillo, 2021). Bank Indonesia (BI) declares that around 5.8 million business people use the QR Code Indonesian Standard (QRIS), which is a payment system using the QR Code method that is easy, fast, and safe in carrying out transaction processes. BI explained that the QRIS will further support the digitization of MSMEs, (Indonesian Economic and Business Data Center, 2021). The increase of SMEs users of QRIS as a form of digitization can be seen in Figure 3. According to the Indonesian Fintech Association and Bank Indonesia (BI), the number of e-money users increased during the pandemic, with digital payments being of great assistance to many individuals and MSME players in their transactions. Figure 4 provides the data on the changes of the number of e-money users. 
Kala'lembang, A. (2021), "Digitalization in increasing SMEs productivity in the post COVID-19 pandemic period", Management and entrepreneurship: trends of development, 2(16), pp. 101-110. Available at: https://doi.org/10.26661/2522-1566/2021-1/16-08.

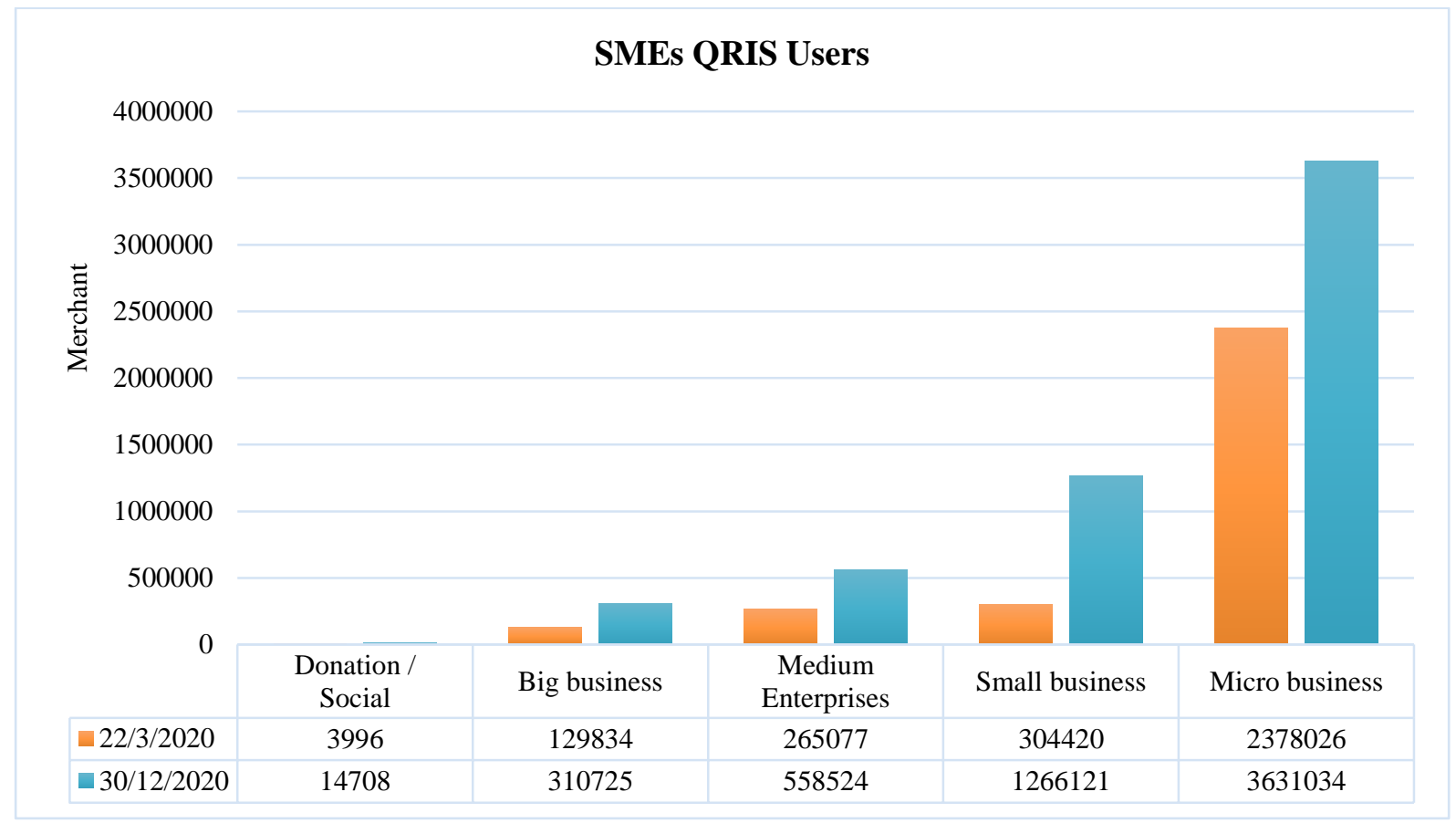

Figure 3. SMEs QRIS Users

Source: Indonesian Economic and Business Data Center, 2021

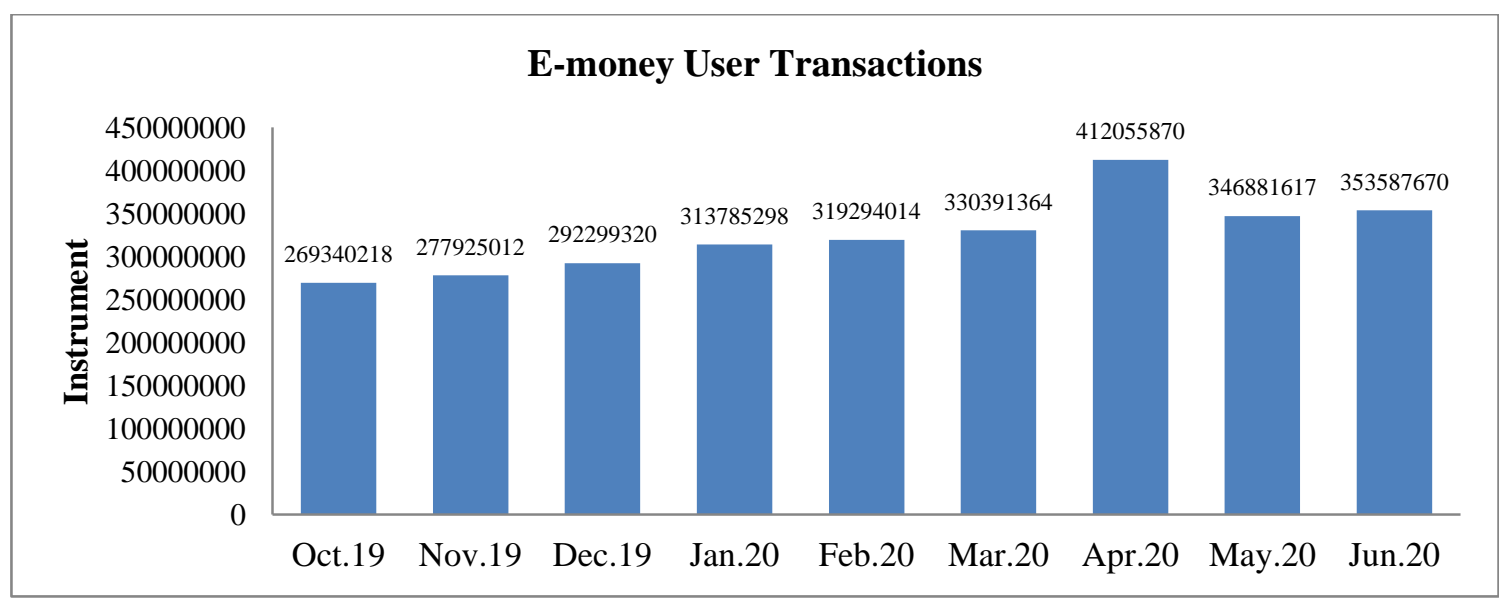

Figure 4. E-money User Transactions

Source: Indonesian Economic and Business Data Center, 2021

In their research of the Italian SMEs, Crupi et al. (2020) argue that digital innovation acts as a source of knowledge capable of shaping the digitalization of SMEs. Digital innovation is not only a forum for knowledge but also plays a role in helping SMEs achieve a higher openness that encourages the exchange of knowledge between business people (Crescenzi et al., 2016). Garzoni et al., (2020) analyzed how digitalization affects the business processes of Apulia SMEs (Southern Italy). Most of the available technology is a digital solution for the production and distribution process that has a relevant impact on the business strategy. Spanish SMEs are encouraged to change their business models and adapt to changing market trends by using digitalization strategies so that 
they have added value and can compete at European and international levels (Gavrila Gavrila and de Lucas Ancillo, 2021).

Such forms of digitization as Facebook, Instagram, Twitter, and the Web are media used by businesses to increase sales that can reach many people while saving costs (Matarazzo et al., 2021). Social media and mobile applications change the strategy of communication, interaction, and collaboration within companies (Lamberton and Rose, 2012). Social media generates a lot of relationships with other people, unlike the traditional system of only approaching one or a few people. The world of digitalization shapes experiences to play an active role in creating customers. Economic development and success are due to the digitalization business model (Parker, Van Alstyne and Choudary, 2016). Social media such as Facebook is a medium of communication and also provides opportunities for SMEs players in running their business. 92\% of SMEs admit that the Facebook application can increase the number of subscribers, while $75 \%$ and $74 \%$ respectively say that it reduces marketing costs and barriers to growth (Indonesian Economic and Business Data Center, 2021). Figure 5 shows the benefits and impact of Facebook for SMEs.

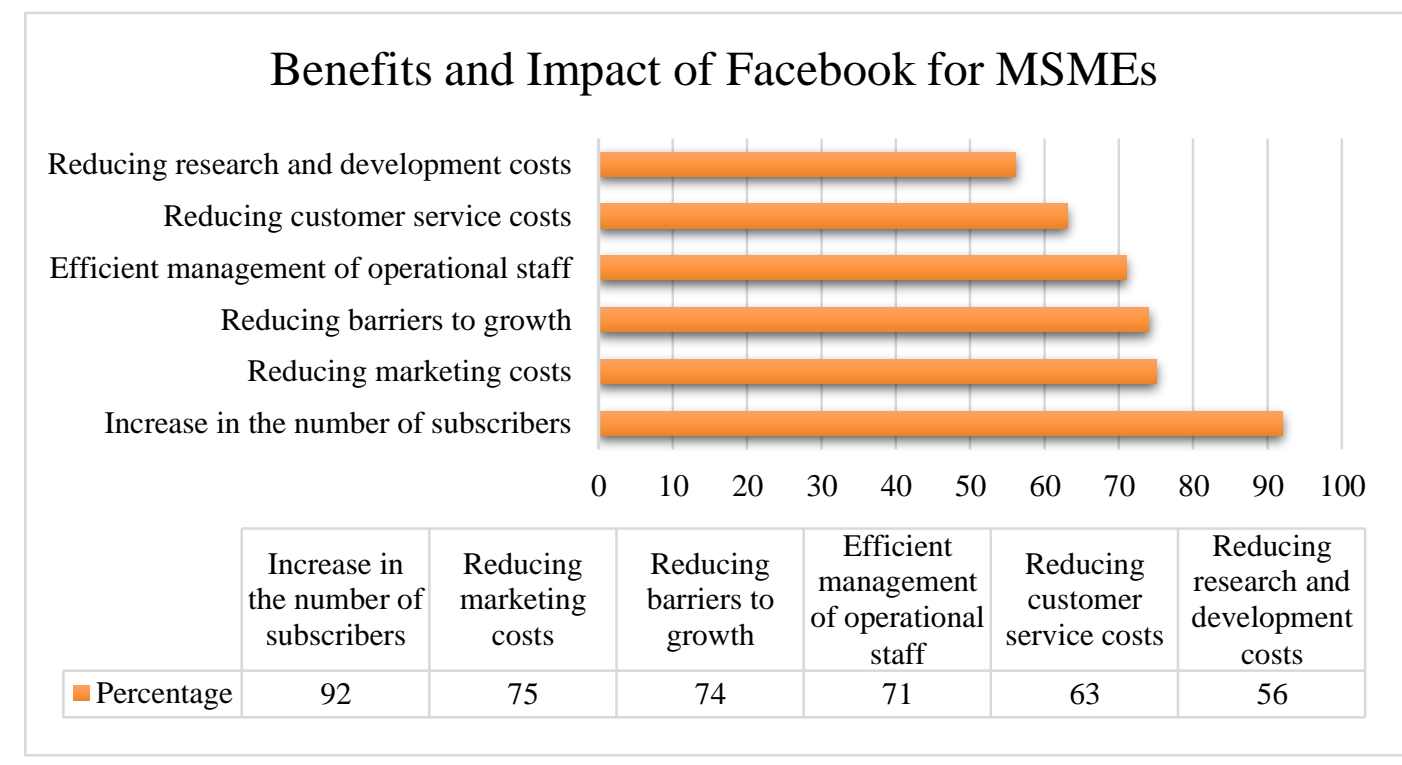

Figure 5. Benefits and Impact of Facebook for SMEs

Source: Indonesian Economic and Business Data Center, 2021

The strength that drives SMEs to adopt digital technology can be seen from the sales orientation where they use e-commerce applications, marketing orientations that enhance the branding of their products; the process improvement can save labor costs, reduce errors in work and accelerate the production process and product development (Lee et al., 2020). SMEs need to adopt ethical, efficient, and sustainable business models to support competition in the global market (Kumar et al., 2020). Digitalization needs to be adopted by SME players as lifestyle and habits have shifted to the technology that makes it easier for every user to meet their needs. Table 1 provides the comparison between digital and traditional users in SMEs that can be used as a consideration in providing quality for using technology. 
Kala'lembang, A. (2021), "Digitalization in increasing SMEs productivity in the post COVID-19 pandemic period", Management and entrepreneurship: trends of development, 2(16), pp. 101-110. Available at: https://doi.org/10.26661/2522-1566/2021-1/16-08.

Table 1

Digital vs Traditional Users

\begin{tabular}{ll}
\hline \multicolumn{1}{c}{ Digitized SMEs } & \multicolumn{1}{c}{ Traditional SMEs } \\
\hline Innovation strategy & Difficulty in innovating \\
\hline Easier transaction process & Slow transaction process \\
$\begin{array}{l}\text { Wider partner on a national and even } \\
\text { international scale }\end{array}$ & Limited partners for certain areas \\
\hline Easier to follow market trends & $\begin{array}{l}\text { Looks stiff and difficult to follow market } \\
\text { developments }\end{array}$ \\
\hline Easier to find new customers & Rely on old customers \\
\hline Create new market opportunities & Difficult to create new markets \\
\hline
\end{tabular}

\section{CONCLUSSION}

The sustainability of SMEs must be maintained since they represent one of the backbones of the economy. Based on the results of reviews from various sources, we conclude that digitization is one of the strategies that can be used and developed to support the sustainability of SMEs. The Industrial Era 4.0 is an era where consumer behavior changes and business people must keep up with these changes so that they continue to exist.

Long before the pandemic hit the world, digitalization was used by various countries to support their daily activities as well as grow their business. Various benefits can be felt, including finding potential customers and retaining them, improvements in communication, saving costs, and better relationships with business partners. SMEs in Indonesia should adopt a digitalization strategy in running their business so that they can survive and compete with other business players. Digitalization is one of the ways of increasing SMEs productivity.

\section{REFERENCES}

Ali, Z., Gongbing, B. and Mehreen, A. (2018), "Does supply chain finance improve SMEs performance? The moderating role of trade digitization", Business Process Management Journal, 26(1), pp.150-167. Available at: http://dx.doi.org/10.1108/bpmj-05-2018-0133.

Arnold, C., Kiel, D. and Voigt, K.-I. (2019), "How the Industrial Internet of Things Changes Business Models in Different Manufacturing Industries", Series on Technology Management, pp.139-168. Available at: http://dx.doi.org/10.1142/9781786347602_0006.

Autio, E., Nambisan, S., Thomas, L. D. W. and Wright, M. (2018), "Digital affordances, spatial affordances, and the genesis of entrepreneurial ecosystems", Strategic Entrepreneurship Journal, 12(1), pp.72-95. Available at: http://dx.doi.org/10.1002/sej.1266.

Bharadwaj, A., Sawy, O. A. El, Pavlou, P. A. and Venkatraman, N. (2013), "Digital Business Strategy: Toward a Next Generation of Insights", MIS Quarterly, 37(2), pp.471-482. Available at: http://dx.doi.org/10.25300/misq/2013/37:2.3.

Caniato, F., Gelsomino, L.M., Perego, A. and Ronchi, S. (2016), "Does finance solve the supply 
chain financing problem?", Supply Chain Management: An International Journal, 21(5), pp.534-549. Available at: http://dx.doi.org/10.1108/scm-11-2015-0436.

Crescenzi, R., Nathan, M. and Rodríguez-Pose, A. (2016), "Do inventors talk to strangers? On proximity and collaborative knowledge creation", Research Policy, 45(1), pp.177-194. Available at: http://dx.doi.org/10.1016/j.respol.2015.07.003.

Crupi, A., Del Sarto, N., Di Minin, A., Gregori, G. L., Lepore, D., Marinelli, L. and Spigarelli, F. (2020), "The digital transformation of SMEs - a new knowledge broker called the digital innovation hub", Journal of Knowledge Management, 24(6), pp.1263-1288. Available at: http://dx.doi.org/10.1108/jkm-11-2019-0623.

Fairchild, A. (2005), "Intelligent matching: integrating efficiencies in the financial supply chain", Supply Chain Management: An International Journal, 10(4), pp.244-248. Available at: http://dx.doi.org/10.1108/13598540510612703.

Fitzgerald, M., Kruschwitz, N., Bonnet, D. and Welch, M. (2013), Embracing Digital Technology: A New Strategic Imperative, Massachusetts Institute of Technology. Available at: https://www.capgemini.com/wpcontent/uploads/2017/07/embracing_digital_technology_a_new_strategic_imperative.pdf (Accessed 20 March 2021).

Garzoni, A., De Turi, I., Secundo, G. and Del Vecchio, P. (2020), "Fostering digital transformation of SMEs: a four levels approach", Management Decision, 58(8), pp.1543-1562. Available at: http://dx.doi.org/10.1108/md-07-2019-0939.

Gavrila Gavrila, S. and de Lucas Ancillo, A. (2021), "Spanish SMEs' digitalization enablers: EReceipt applications to the offline retail market", Technological Forecasting and Social Change, 162, p.120381. Available at: http://dx.doi.org/10.1016/j.techfore.2020.120381.

Herman (2020), "2,322 Cooperatives and 185,184 MSMEs Affected by Covid-19”, Beritasatu. https://www.beritasatu.com/ekonomi/642537/2322-koperasi-dan-185184-umkm-terdampakcovid19 (Accessed 20 March 2021), (in Indonesian).

Indonesian Economic and Business Data Center (2021). Available at: https://databoks.katadata.co.id (Accessed 20 March 2021), (in Indonesian).

Jin Zhang, J., Lichtenstein, Y. and Gander, J. (2015), "Designing scalable digital business models", Business Models and Modelling, pp.241-277. Available at: http://dx.doi.org/10.1108/s0742332220150000033006.

Khalique, M., Bontis, N., Bin Shaari, J. A. N., Yaacob, M. R. and Ngah, R. (2018), "Intellectual capital and organisational performance in Malaysian knowledge-intensive SMEs", International Journal of Learning and Intellectual Capital, 15(1), pp.20-36. Available at: http://dx.doi.org/10.1504/ijlic.2018.088345.

Kumar, R., Singh, R. K. and Dwivedi, Y. K. (2020), "Application of industry 4.0 technologies in SMEs for ethical and sustainable operations: Analysis of challenges", Journal of Cleaner Production, 275, 124063. Available at: http://dx.doi.org/10.1016/j.jclepro.2020.124063.

Lamberton, C. P. and Rose, R. L. (2012), "When is ours better than mine? A framework for understanding and altering participation in commercial sharing systems", Journal of Marketing, 76(4), pp.109-125. Available at: http://dx.doi.org/10.1509/jm.10.0368.

Lawal, A.A. and Akingbade, W.A. (2018), "Diversity Management and Organizational Performance: Evidence from Nigerian Small and Medium Enterprises", Journal of Knowledge Globalization, 10(1), p. 1-25. Available at: http://www.journal.kglobal.org/index.php/jkg/article/view/244 (Accessed 20 March 2021).

Lee, Y. Y., Falahat, M. and Sia, B. K. (2020), "Drivers of digital adoption: a multiple case analysis among low and high-tech industries in Malaysia". Asia-Pacific Journal of Business Administration, 13(1), pp.80-97. Available at: http://dx.doi.org/10.1108/apjba-05-2019-0093.

Lorenz, R., Benninghaus, C., Friedli, T. and Netland, T. H. (2020), "Digitization of manufacturing: the role of external search", International Journal of Operations \& Production Management, 
Kala'lembang, A. (2021), "Digitalization in increasing SMEs productivity in the post COVID-19 pandemic period", Management and entrepreneurship: trends of development, 2(16), pp. 101-110. Available at: https://doi.org/10.26661/2522-1566/2021-1/16-08.

40(7/8), pp.1129-1152. Available at: http://dx.doi.org/10.1108/ijopm-06-2019-0498.

Maiti, M. and Kayal, P. (2017), "Digitization: Its Impact on Economic Development \& Trade", Asian Economic and Financial Review, 7(6), pp.541-549. Available at: http://dx.doi.org/10.18488/journal.aefr.2017.76.541.549.

Matarazzo, M., Penco, L., Profumo, G. and Quaglia, R. (2021), "Digital transformation and customer value creation in Made in Italy SMEs: A dynamic capabilities perspective", Journal of Business Research, 123, pp.642-656. Available at: http://dx.doi.org/10.1016/j.jbusres.2020.10.033.

Nambisan, S., Wright, M. and Feldman, M. (2019), "The digital transformation of innovation and entrepreneurship: Progress, challenges and key themes", Research Policy, 48(8), 103773. Available at: http://dx.doi.org/10.1016/j.respol.2019.03.018.

Oliveira, L., Fleury, A. and Fleury, M. T. (2021), "Digital power: Value chain upgrading in an age of digitization", International Business Review, 101850. Available at: http://dx.doi.org/10.1016/j.ibusrev.2021.101850.

Parker, G. G., Van Alstyne, M. W. and Choudary, S. P. (2020), "Platform revolution: How networked markets are transforming the economy and how to make them work for you", Studia Medioznawcze, 1, pp.139-144. Available at: http://dx.doi.org/10.33077/uw.24511617.ms.2017.68.418.

Perego, A. and Salgaro, A. (2010), "Assessing the benefits of B2B trade cycle integration: a model in the home appliances industry", Benchmarking: An International Journal, 17(4), pp.616631. Available at: http://dx.doi.org/10.1108/14635771011060611.

Schuh, G., Anderl, R., Gausemeier, J., Hompel, M. and Wahlster, W. (2017), Industrie 4.0 Maturity Index - Managing the Digital Transformation of Companies. Acatech STUDY. Available at: https://en.acatech.de/publication/industrie-4-0-maturity-index-managing-the-digitaltransformation-of-companies/ (Accessed 20 March 2021).

Steenkamp, J.-B.E.M. (2020), "Global Brand Building and Management in the Digital Age", Journal of International Marketing, 28(1), pp.13-27. Available at: http://dx.doi.org/10.1177/1069031x19894946.

Svadberg, S., Holand, A. and Breunig, K. J. (2019), "Beyond the Hype: A Bibliometric Analysis Deconstructing Research on Digitalization", Technology Innovation Management Review, 9(10), pp.38-50. Available at: http://dx.doi.org/10.22215/timreview/1274.

Taiminen, H.M. and Karjaluoto, H. (2015), "The usage of digital marketing channels in SMEs", Journal of Small Business and Enterprise Development, 22(4), pp.633-651. Available at: http://dx.doi.org/10.1108/jsbed-05-2013-0073.

\title{
РОЛЬ ЦИФРОВІЗАЦІЇ У ПІДВИЩЕННІ ПРОДУКТИВНОСТІ МСП У ПОСТ-ПАНДЕМІЧНИЙ ПЕРІОД COVID-19
}

\author{
Adriani Kala'lembang \\ Universitas Negeri Malang \\ Indonesia
}

Пандемія COVID-19 спричинила глобальне потрясіння, що призвело до затримки економічного зростання та негативного впливу на стійкість МСП. Паніка виникла внаслідок неконтрольованих витрат, які було здійснено 3 метою сприяння відновленню. Це дослідження має на меті вивчити можливості пандемії після COVID-19 для МСП, використовуючи цифровізацію. Використовуючи цифровізацію, МСП легко залучити та утримати потенційних клієнтів, покращити спілкування, заощадити витрати та покращити стосунки 3 діловими партнерами. Автор розглядає цифровізацію як розумне рішення для підвищення продуктивності МСП.

Ключові слова: MCП, COVID-19, цифровізація. 


\title{
РОЛЬ ЦИФРОВИЗАЦИИ В ПОВЫШЕНИИ ПРОИЗВОДИТЕЛЬНОСТИ МСП В ПОСТ-ПАНДЕМИЧЕСКИЙ ПЕРИОД COVID-19
}

\author{
Adriani Kala'lembang \\ Universitas Negeri Malang \\ Indonesia
}

\begin{abstract}
Пандемия COVID-19 вызвала глобальное потрясение, что привело к задержке экономического роста и негативному влиянию на устойчивость МСП. Паника возникла в результате неконтролируемых расходов, осуществленных с целью содействия восстановлению. Это исследование имеет целью изучить возможности пандемии после COVID-19 для МCП, используя цифровизацию. Используя цифровизацию, МСП легко привлечь и удержать потенциальных клиентов, улучшить общение, сэкономить расходы и улучшить отношения с деловыми партнерами. Автор рассматривает цифровизацию как разумное решение для повышения производительности МСП.
\end{abstract}

Ключевые слова: MCП, COVID-19, цифровизация. 